\title{
Evolution of American Federalism
}

\author{
Sun Hao \\ School of politics and public administration \\ China University of Political Science and Law \\ Beijing, China
}

Keywords: Centralization; Decentralization; Dual federalism; Cooperative federalism; New federalism

\begin{abstract}
The United States federal system experienced a development process which included "federalism", “cooperative federalism”, "new federalism". In the beginning, the power relations between federal and state were kept balance relatively. Later, the relative balance was broken. Final, there was a new process that re-process the relative balance of power. In short, each period exhibit different characteristics.
\end{abstract}

\section{Introduction}

After the 1787 Constitution was adopted, the United States abolished the Confederation and established Federalism. The establish of federalism not only provide American people a strong federal government, but also give a effective protection to the rights of the state and the people, which completely changed the political disorder in the previous confederation period. Federalism is a decentralized system, "Sovereignty shared by two or more levels of government in some matters, the national government is the highest; On other matters, state, regional or provincial government is the highest."[1]1The national affairs, such as defense, foreign affairs, currency, interstate commerce governed solely by the federal government. Affairs within the state, such as education , public health, social welfare, intrastate commerce is exclusively the jurisdiction of State. However, federalism is no static. As the development of us political and economic, the United States has undergone a variety of changes in federalism. The distribution of power between the federal government and the state government has undergone several significant adjustment. Far from the adoption of the constitution, roughly forming such a evolution that is decentralization, centralization - decentralization again.

\section{The period of decentralization (1789 - Late 19th century)}

American federalism in this period generally known as "dual federalism". Under the "dual federalism", federal government and state government exercised their power within range of the constitution separately and any party can't intervene with the field that belonging to other party. In this case , there is little cooperate between two sides. The powers between federal government and state government maintain a long-term balance.

Federal system established by the Constitution of 1787 , seems to be a victory of the federalists, in fact, a compromise of federalism and state chauvinism. In a very long period of time after the adoption the Constitution, the debate between Federalists who support nationalism and Anti-Federalists or Democratic Republican Federalist who support state's rights was still fierce. Federalists believed that the Federal Constitution is the contract of the people, and the people have been granted full authority to the federal government. Therefore, it is necessary to give a broad interpretation of federal power, unless prohibited by the Constitution expressly. On the other hand, the advocates of state's rights believe that safeguard state's rights is to safeguard the rights and freedoms of the people because state government are more close to people. The ten amendments of the Constitution (the Bill of Rights) were adopted in 1789. Tenth Amendment which states: the 
powers not delegated to the United states by the Constitution, nor prohibited by it to the states, are reserved to the states respectively, or to the people. It is no doubt that a victory of the advocates of state's rights.

During this period, the supreme Court has played a role in supporting the expansion of federal power. In the "McCulloch v Maryland" case, the judgment of the supreme court firmly safeguard the authority of the federal government. In 1826, in spite of opposition from the United States, Congress passed an act titled "An Act to Incorporate the subscribers to the Bank of the United States" which provided for the incorporation of the Second Bank of the United States. In 1919, the McCulloch, head of the Baltimore Branch of the Second Bank of the United States, refuse to pay the taxes to the State of Maryland. The case was appealed to the Maryland Count of Appeals where the state of Maryland argued that "the Constitution is silent on the subject of banks". It was Maryland's contention that because the constitution did not specifically state that the federal government was authorized to charter a bank, the Bank of United States was unconstitutional. The case was the appealed to the Supreme Court. The Supreme court determined that Congress did have the power to create the Bank. Chief Justice Marshall supported the Court's opinion textually by invoking the Necessary and Proper Clause, which Permits Congress to seek an objective that is within its enumerated powers so long as it is rationally related to the objective and not forbidden by the Constitution. Chief Justice Marshall also determined that Maryland may not tax the bank without violating the Constitution The Court voided the tax on the grounds that is was unconstitutional. The opinion stated that Congress has implied powers that need to be related to the text of the Constitution, but need not be enumerated within the text. This case was a seminal moment in the formation of a balance between federalism, federal power, and states' powers.

In 1824, in the case of "Gibbons V Ogden", Marshall made a judgment which also had a positive influence on the expansion of the federal government authority. The state of New York had granted the ferry franchise between New York and New Jersey to a businessman Ogden while another businessman Gibbons operated the same line business granted by federal license agreement coast. Ogden complained to the New York state court. Then, the New York state court determined that Gibbons must stop operating the business. According to the ship's license law passed by Congress, Gibbons claiming that the state law violated the federal license granted to his shipping right and appeal the case to the Supreme Court. Marshall announced that franchise license was illegal because it violated the interstate commerce power of Congress. When trade involving between two or more states, the power of Congress can extend to the internal of a state. Marshall's opinion affirmed such a principle that national power is superior to state power. The terms "necessary and proper " and trade terms are generalized national powers conferred.[2]2

In 1820, on the issue of whether the new state Missouri could become a slave states, federal rights advocates and state rights advocates had a bitter disputed. At the time, the number of Free States and slave states are equal in United States. Both the advocates of federal rights and the advocates of state rights hoped to expand its sphere of influence. The tow sides eventually reached a compromise: Missouri was a slave state. At the same time, in order to maintain the balance of representation of both north and south in the senate, Maine, a new state separation from Massachusetts, was a free state.

In 1832, the congress of South Carolina state was control by a group of advocates of states rights. They challenged the federal authority by against the new tariff law. They claimed that the new tariff law unauthorized and therefore not binding on the United States, and threatened to withdraw from the Union. On the one hand ,the federal was pressing military pressure to the South Carolina state , and On the other hand, reducing tariffs to make concessions. Under the federal government's carrot and stick, the two sides eventually reached a compromise.

In 1857, in the case of "Dred Scott", the Supreme Court made a ruling to maintain states' rights. Dred Scott, a black slave, lived for four years in the north. After his master's death, according to federal law, "the Missouri Compromise Act ", he applied to free for Missouri. However, the 
Supreme Court ruled that the "the Missouri Compromise" beyond the constitutional power of Congress which has no right to abolish slavery anywhere in the United States.

The struggle between Federalist and supporter of state's rights culminated in the American Civil War. The 1861 American Civil war, not only a war between the two systems of north and south, but also the war between federalists and the advocates of states' rights. Before the Civil War, on the balance of power relations, the national government as the main party which have broad powers to put more emphasis on states' rights constraints on federal power. The federal government plays the role of the states "servant".[3] 3Civil war ended with the victory of federalist. Since then, although the basic framework of dual federalism has no fundamentally changed, the North's victory makes the powers of the federal government began to rise steadily. That lead to a new period of development of "dual federalism".

After the war, federal authority firstly expanded in the aspect of citizenship, which is reflected in the Thirteenth、Fourteenth、Fifteenth constitutional amendment. Thirteenth Amendment prohibits slavery and states to implement mandatory service. Fourteenth Amendment prohibits states restrict the development of the privileges or immunity of citizens of the United States of any law. States give any people equal protection of the law. Fifteenth Amendment prohibits to refuse to grant citizenship suffrage in the reason of race, color, etc.

In this period, although the power of the federal was showing the trend of expansion, but on the whole, it is a partial, limited, state governments still cling to their positions. In fact, the basic structure of "dual federalism" remains intact. Because the power of the federal and state kept balanced, we might as well call this time as “decentralization” period in American history.

\section{The centralized period of the federal government (late 19th century-1960s)}

Late 19th century, the power of the federal signed of expansion into the economy, which was mainly due to significant changes in the economic situation occurred. Prior to the nineteenth century, the classical liberal economic ideas in the United States were occupying the mainstream. The government rarely direct intervention on the economy and let the market self-regulation mechanisms. This laissea-faire economic system greatly contribute to the prosperity and the developed industrial countries.The United States from an agricultural country became into a developed industrial countries. However, free competition also brought a negative impact. In the late nineteenth century, there gradually formed a number of large monopolies which could manipulate the production and sale of goods and influence national policy to the detriment of small capitalists and consumers by the using of economic forces. That would require the federal government to strengthen the intervention in the economy.

The performance of the federal government to intervene in the economy to expand as follow: in 1887, Congress passed the "Interstate Commerce Act", the Interstate commerce Commission was established under the law is the first federal agency managing the national economy, many of the original jurisdiction of the state government Business activities are integrated into the jurisdiction of the federal government. In 1890, Congress enacted the "Sherman Antitrust Act", which is the first national US antitrust legislation. Since then, the federal government can borrow in the name of exercising some antitrust authority belonged to the state. In 1913, Congress passed the "Federal Reserve Act" and establishment of a series of Federal Reserve Bank, the formation of the federal Reserve Bank system, which allows the federal government has regulated national financial capabilities. That same year, Congress passed the sixteenth amendment to the Constitution gives Congress power to levy income taxes. The federal government has a new source of tax revenue that greatly improving the management capacity of the national economy and social affairs.

In 1910, President Theodore Roosevelt launched a reform program named "new nationalism". "New Nationalism" trying to expand the powers of the federal government, advocated the strengthening of the federal government in a market economy, the protection of labor rights and the protection of natural resources and other aspects of the role. 
In 1930, "dual federalism" had come to the end of history and replaced by a "cooperative federalism”. "Cooperative Federalism” stressed the different levels of government in the provision of effective public services are not separated from each other, but rather to establish a cooperative partnership. American political scientist Morton Gro Tianjin Adams will be "cooperative federalism" as a metaphor for "marble cake", to distinguish it from similar "Layer Cake" and "dual federalism"[4]4 Cooperative federalism main features are: policy decision to focus the federal government, the process of policy implementation performance of mutual between all levels of government cooperation. "Cooperative federalism" appearance reflects the rising power of state governments to the federal government's declining power.

After the "Great Depression" outbreak, state government's inability to solve the problems faced. In this context, in order to strengthen state intervention is characterized by "New Deal" came into being. During the "New Deal”, Congress passed the "Emergency Banking Act", "Agricultural Adjustment Method", "Social Security Act" and other bills; while the establishment of a national revival Authority, the Department of Agriculture of economic adjustment, the National Labor Relations Board and a series of new federal agency, so the powers of the federal government in the financial, industrial, agricultural, social relief, social welfare and many other areas of expansion. "New Deal" to make the balance of the power favored the federal government, the relationship between the federal government and state governments to break the "dual federalism" boundaries. Some people think that the "New Deal" is the relationship between federal and state history on the federal "geological fault line".[5] 5

The power expand of the federal government reached its peak in the Johnson presidency during the 1960. Under the slogan "great society", President Johnson introduced a series of favorable policies to expand federal power. For example, in the aspect of civil rights, Congress adopted the "1964 Civil Rights Act" which prohibits job discrimination and all public facilities isolation or discrimination against blacks. In education, the "Higher Education Act of 1965", the federal government provides scholarships and low-interest loans for college students. In health care, Congress approved the "Social Security Act" to provide federal funding for health care costs of the elderly. During the Johnson administration, federal power expanded to all fields, hence this period is called federalism "creative federalism".

Although Federal and state governments are no legally exist affiliation, because of the federal government dominance in taxation, the federal government can influence the affairs within the state through funding. The main form of federal funding in this period is categorical-formula grant. The use of categorical-formula and additional appropriations must be under strict conditions. State which accept funding must come up with some funds from the state to implement federal programs in fiscal. Therefore the power of state government in the use of such grants autonomy are quite small. Before world War II, the federal government's financial support to the state government is very limited. In 1902, the subsidies accounted for only $1 \%$ of the revenues of state and local government.[6] 6 After World War II, the federal government funding for state and local governments were rising year after year. Between 1955 to 1980, federal funding of 17.6\% average annual growth rate, its share total state spending rose from $10.2 \%$ to $25.8 \%$.

Expanded powers of intervention of the federal government were making the federal government's fiscal spending rose rapidly form 1925 to 1941, per capital expenditure of the federal government increased by about $400 \%$. Before the 1930s, Americans are seen as appendages only city states, the funds are mainly from the state government. In 1940s, the situation changed. Only in 1940 , the federal government will be $\$ 278$ million in grant funds directly allocated to local governments to pay for the construction of public housing and public woks projects. In 1950s, the federal government grants to local governments and then expanded to urban construction projects, the construction of airports and other fields.

${ }^{4}$ [4] M. Grodzins, The American system(Rand McNally 1966),pp.3-4

${ }^{5}[5]$ Sandrs S.Osbourn: Federalism, Library of Congress, P.38

${ }^{6}[6]$ Joseph Paateman: The US tax policy , Beijing Publishing House, P. 316 
During the "Cooperative federalism” period, the federal government's power was in a dominant position clearly. "Centralization" is the main characteristic of this period of federalism.

\section{Again decentralization period (from the Nixon administration during the 1970s-present)}

The late 1960s, the drawbacks of excessive concentration of power began to emerge: the huge bureaucracy, fiscal deficit, the rapid increase in debt, unemployment surge. By the 1970s, the US economy has never been the "stagflation", that continued economic stagnation accompanied by serious inflation. The philosophy of "Big government" from Roosevelt to Johnson's is the root cause of this situation. To overcome the "big government" malpractice, President Nixon proposed the "New Federalism" concept which advocated back the power to the states and people. That can relieve the excessive power concentrated of federal government since the "New Deal " period. Nixon's public statements on television: "Nearly one-third century, Washington has absolute authority and responsibility to control, but also to consolidate the sources of income. Now, we will reverse this trend and back the greater the responsibility to the states. Such practice is definitely not escape the problem, on the contrary, but it is better to solve the drawbacks of prescription."[7] 7“New Federalism” reforms include six aspects: revenue sharing, welfare reform, full employment, environmental protection, national health insurance programs and administrative reforms. Where revenue sharing is the core problem. This plan will be the federal government funds a portion of the annual income allocated to state and local governments state and local governments from discretionary. In 1972, Congress passed the "State and Local Fiscal Assistance Act", ready to be $\$ 30.2$ billion over five years of revenue allocated to state and local governments.

After Reagan took office in 1981, the relationship between the federal government and local governments continue to follow Nixon's "New Federalism Reform". In accordance with the "Economic Recovery Act", the relationship between the federal and state governments Reagan carried out a wide range of adjustment. On the one hand, the Reagan administration the federal government's power and social responsibility part of the devolution to the states and local governments. On the other hand ,the Reagan administration with plenty of LSG replace more restrictive categorical-formula grant. In 1982, the Reagan administration proposed two plans: 1. From the 1984 financial year, the federal government assume all social Medicaid and all other matters will be handed over to state governments under their jurisdiction. 2. From 1984, including education, 43 federal community development grant program classification, transportation, and other areas, including social welfare, together with the implementation of the funds to pay for these plans to gradually shift to the states. In 1988, all states had fully controlled these plans.[8]8

During the Reagan administration, state and local governments have more administrative and financial authority. Which is mainly manifested the proportion of income and expenditure of the federal government's finances continue to decline, while the proportion of revenue and expenditure of the state and local governments have corresponding increase in some degree.

Between 1981 to 1988, the federal government's fiscal revenue accounted for the proportion of revenue decreased from $67 \%$ to $64 \%$, and the expenditure in the national fiscal expenditure has dropped from $70.3 \%$ to $67.9 \%$. "New Federalism" make the state administrative agencies to streamline and reduce bureaucracy in the political process, and greatly improving the efficiency of government.

In 1995, Republicans had controlled of Congress. With the support of President Clinton, the Republican successfully carried out a large reform in the relationship between federal and state. More social functions have been given the state. Some people called for this reform "Republican Revolution". Federal government often make commission request to state and local governments without federal funding. In response, state and local officials often that they protest against unfunded federal commission has finally produced results. In 1995, Congress passed the "no funds entrusted Reform Act". The Act required the federal government to find out the type of the decree,

7[7] zheng Shizhong: The United States Government and Politics, Central University Press, P.14 
subject to the cost of the decree and the resources available, and the report on the legislation that came to be described accounting method is superior stagnation state law. The bill also gives some appropriate constrains to the Congress itself, commissioned by a congressional committee in favor of federal legislation must be concerned commission in its report, and explain the state and local governments are required to complete the commission fee. If congress committee does no intend to provide full financial support to the commission, then it must be given a reasonable explanation why state and local governments should bear the costs.

In 1990s, the Supreme Court ruling on the powers of Congress have also been limited. For example, in the case of "United State V. Lopez", the Supreme Court invoked a federal law which prohibiting gun ownership vetoed a radius of one thousand feet in the shool-wide according the Tenth Amendment of the Constitution. Congressional defense said he was exercising constitutional commerce power, while the Supreme Court claimed that the ban has nothing to do with commerce or any form of economic activity. In the case of "Printz v. United States", the Supreme Court rejected part of the federal "handgun violence Prevention law" that requires local law enforcement officials to verify it is possible to buy a gun's background. Supreme Count held that this provision violates the Tenth Amendment and Congress could require federal officials to take such action, but state official are not entitled to do this.

In 1993, President Clinton proposed a "Reinventing Government" slogan, which decided to adjust the power relationship between the government system and creating a low-cost government. Congress gave the president of policy support. In 1995, Congress passed the "Federal does no provide funding Reform Act”, and through the whole batch shall grant to support rural development and social welfare undertakings related laws. Reform of the Clinton Administration has achieved some success, from 1996 to 1997, the country relies on federal funding of human welfare reducing 120 million. The government's macro-control economy performed so that the federal deficit is declining, in 1993 to 1997, from \$250 billion dropped to \$ 217 billion. Surpluses began to appear in 1997. In 2000 the surplus of federal government amounted to \$ 256 billion.

President George W. Bush who took office in 2001. The relationship between the federal government and the state governments was adjust, which also adhere to the "new federalism".He claimed reduce the power of the federal claims and accordingly expand the powers of the state. Especially in terms of social welfare, Bush advocated the privatization of social welfare in order to reduce the burden on the federal government pensions. However, with the expansion of the war on terror, federal power again showing signs of expansion. American federal system is a great experiment in the human face of established political order in the range of a vast territory. However, this system is no static, which generally experienced in a process of "decentralization centralization - decentralization again". These changes to adapt to the realities of the United States in different historical periods, making the US federal system has become an integral part of the constitutional system of the United States to support the carrier, to promote economic and social development of the United States has played a huge role in promoting.

\section{References}

[1]Wilson, James Q. and John J.Dilulio, Jr. American Government Institutions and Politics. Lexington,D.C Heath and Company, 1995.P. A-49

[2] Thomas Patterson: The US political culture, Oriental Press, 2007, p. 84.

[3]Boyd, E.:American Federalism, 1776 to 1997: Significant Events,Analyst in American National Government-Government Division, p.16.

[4] M·Grodzins, The American system(Rand McNally 1966),pp.3-4

[5] Sandrs S.Osbourn: Federalism, Library of Congress, P.38

[6] Joseph Paateman: The US tax policy, Beijing Publishing House, P. 316

[7] zheng Shizhong: The United States Government and Politics, Central University Press, P.14 
[8] Hawkins, R.B. Jr. ed. American federalism: a New Partnership for the Republic . San Francisco: Institute for Contemporary studies, P341. 